Barttomiej Kurzyk

\title{
Lokowanie produktu i inne formy integracji treści promocyjnych i natywnych - problemy definicyjne
}

\section{Przyczyny zainteresowania niestandardowymi instrumentami komunikacji marketingowej}

Ostatnie lata przyniosły duże zainteresowanie marketerów niestandardowymi instrumentami komunikacji marketingowej. Jest to spowodowane z jednej strony rosnącym szumem reklamowym, z drugiej - coraz większym stopniem irytacji odbiorców wszechobecną reklamą. Liczba otaczających nas komunikatów komercyjnych stale rośnie. Jest ona trudna do oszacowania, specjaliści jednak podejmują takie próby. Uważa się, że mieszkańcy miast w USA mieli kontakt z 2000 komunikatów komercyjnych dziennie już 30 lat temu. Dzisiaj ta liczba może sięgać nawet 5000 komunikatów ${ }^{1}$. W Polsce badania tego typu realizowane są dość rzadko. Dom mediowy Starcom szacował w 2004 roku liczbę reklam docierających w tygodniu do przeciętnego konsumenta na 873 (wzrost o 19\% w porównaniu z rokiem 2001). Jednocześnie liczba reklam telewizyjnych docierających codziennie do mieszkańca Polski wzrosła z 39 w roku 2000 do 62 w roku $2004^{2}$.

Taki natłok docierających do konsumentów komunikatów prowadzi do zmian w opiniach o działalności reklamowej firm. W Polsce znane są dwa projekty ciągłe, które obrazują stosunek Polaków do reklamy. Według realizowanych przez Instytut Ipsos w 2005 roku badań, odsetek osób deklarujących zmienianie kanału telewizyjnego podczas trwania bloku reklamowego wzrósł o $10 \% \mathrm{w}$ stosunku do roku 2000 i aż o 30\% w porównaniu z rokiem 1995. Jednocześnie odsetek osób deklarujących uważne oglądanie reklam w bloku spadł do poziomu 4\%, a więc ponad czterokrotnie mniejszego niż w 1995 roku.

${ }^{1}$ L. Story, Anywhere the Eye Can See, It's Likely to See an Ad, „New York Times”, 15.01.2007, http://www.nytimes.com/2007/01/15/business/media/15everywhere.html [dostęp: 10.02.2008].

${ }^{2}$ Starcom, Startrack - Polacy, media, reklama, raport http://www.starcom.com.pl/publikacje. shtml/12 [dostęp: 10.06.2008]. 
Obecnie spore zainteresowanie mediów zyskuje dom mediowy OMD, prowadząc projekt „Wskaźnik irytacji reklamą”. W projekcie bierze udział miejska próba ponad 300 respondentów w wieku 15-59 lat, odpowiadając na pytanie o to, w jakim stopniu w skali 1-10 przeszkadzały im reklamy, z którymi zetknęli się w różnych mediach. W grudniu 2012 r. średni wskaźnik ukształtował się na poziomie 6,4, przy 44\% respondentów, którzy określali swoją irytację reklamą jako wysoką (oceny 8-10 w skali 1-10). W grudniu 2009 r. wskaźnik kształtował się na poziomie ok. 5,4, przy odsetku osób najsilniej zirytowanych reklamą na poziomie ok. 31\% ${ }^{3}$.

W obliczu takich reakcji publiczności na rosnący szum reklamowy, ostatnie lata przyniosły wzrost zainteresowania marketerów alternatywnymi formami komunikacji marketingowej - takimi jak: lokowanie produktu (product placement) ${ }^{4}$, ambient media, marketing wirusowy, marketing mobilny, marketing partyzancki, marketing kontrowersyjny, entertainment marketing i marketing katarktyczny ${ }^{5}$.

W centrum zainteresowani autora tego artykułu leżą te instrumenty komunikacji marketingowej, które wykorzystują łączenie komunikatów promocyjnych i treści artystycznych, rozrywkowych lub informacyjnych. Do tego typu instrumentów należą lokowanie produktu, branded entertainment i reklama natywna.

\section{Istota lokowania produktu}

Nowoczesne, niestandardowe instrumenty komunikacji marketingowej stale ewoluują - marketerzy, dążąc do wyróżnienia swoich przekazów na tle konkurencji, do wybicia się ponad szum reklamowy, stale testują i wdrażają nowe rozwiązania, szukając najskuteczniejszych metod i technik dotarcia do odbiorców. Eksperymentując, marketerzy w kreatywny sposób przełamują schematy, łączą różne techniki komunikacji, wymyślają nowe. Takie działania, w połączeniu z gwałtownym rozwojem technologii komunikacyjnej, znajdują odzwierciedlenie w trudnościach zdefiniowania nowoczesnych instrumentów komunikacji marketingowej.

Prześledźmy problemy definicyjne na przykładzie lokowania produktu. Jest to niezwykle elastyczny instrument komunikacji marketingowej. Znajduje to wyraz w dostępnych w literaturze przedmiotu definicjach tego pojęcia. Mimo że mo-

${ }^{3}$ OMD, Polacy mają dość reklam, http://omd.pl/wskaznik-irytacji-reklama-bardzo-wysokiale-na-stabilnym-poziomie [dostęp: 10.10.2013].

${ }^{4}$ Termin „lokowanie produktu” został upowszechniony wraz z wejściem w życie nowelizacji ustawy o radiofonii i telewizji z 2011 r. Do tego momentu najczęściej w użyciu pozostawał termin anglojęzyczny, product placement. W artykule posługuję się obiema formami wymiennie.

5 Por. B. Pilarczyk, Niestandardowe formy komunikacji marketingowej, „Acta Universitatis Lodziensis" 2004, Folia Oeconomica 179, s. 381. 
żemy zidentyfikować ich przynajmniej kilkanaście, różnice między nimi mają raczej jednak szczegółowy, a nie podstawowy charakter.

Wszyscy autorzy zgadzają się co do istoty zjawiska product placement a więc umieszczania produktów lub marek w akcji filmów kinowych, programów telewizyjnych bądź w innych mediach. Pojawiają się jednak wyraźne różnice między definicjami - na polach mediów, w których może być stosowany product placement, płatnego charakteru, klasyfikacji lokowania produktów w strukturze innych instrumentów komunikacji marketingowej, celu wykorzystania czy sposobu ekspozycji marki w nośniku.

Podsumowanie różnic między wybranymi definicjami product placement zawiera tab. 1.

Tabela 1. Przegląd definicji productplacement

\begin{tabular}{|c|c|c|c|c|c|}
\hline Autor & Nośniki & $\begin{array}{c}\text { Płatny } \\
\text { charakter }\end{array}$ & $\begin{array}{c}\text { Klasyfi- } \\
\text { kacja }\end{array}$ & $\begin{array}{c}\text { Określenie } \\
\text { celu }\end{array}$ & Rodzaj ekspozycji \\
\hline Balasubramaniam $^{a}$ & $\begin{array}{l}\text { Film lub pro- } \\
\text { gram telewi- } \\
\text { zyjny }\end{array}$ & Płatne & - & $\begin{array}{l}\text { Wpływanie } \\
\text { na widow- } \\
\text { nię kinową } \\
\text { (lub telewi- } \\
\text { zyjną) }\end{array}$ & $\begin{array}{l}\text { Wiadomość do- } \\
\text { tycząca produktu } \\
\text { - planowa i nie- } \\
\text { nachalna - przez } \\
\text { wprowadzenie } \\
\text { markowego pro- } \\
\text { duktu w świat fil- } \\
\text { mu (lub programu } \\
\text { telewizyjnego) }\end{array}$ \\
\hline${\text { Malarski }{ }^{b}}$ & $\begin{array}{l}\text { Programy } \\
\text { TV, seriale } \\
\text { TV, sztuki } \\
\text { teatralne itp., } \\
\text { poza blokami } \\
\text { reklamowymi, } \\
\text { jak również } \\
\text { w prasie }\end{array}$ & - & - & - & $\begin{array}{l}\text { Ukazywanie } \\
\text { w sposób pozornie } \\
\text { nie zamierzony } \\
\text { znaku towarowego } \\
\text { lub nazwy określo- } \\
\text { nego produktu }\end{array}$ \\
\hline Gupta, Gould ${ }^{c}$ & Filmy & $\begin{array}{l}\text { W zamian } \\
\text { za płat- } \\
\text { ność lub } \\
\text { za inne } \\
\text { korzyści } \\
\text { - np. pro- } \\
\text { mocyjne }\end{array}$ & - & $\begin{array}{l}\text { Prezentacja } \\
\text { marek }\end{array}$ & Prezentacja marek \\
\hline $\begin{array}{l}\text { Przybyłowski, } \\
\text { Hartley, } \\
\text { Kerin, Rudelius }^{d}\end{array}$ & Film fabularny & $\begin{array}{l}\text { Producent } \\
\text { płaci za } \\
\text { przywilej }\end{array}$ & $\begin{array}{l}\text { Metoda } \\
\text { reklamy }\end{array}$ & - & $\begin{array}{l}\text { Umieszczenie da- } \\
\text { nej marki produktu }\end{array}$ \\
\hline
\end{tabular}


Tabela 1 (cd.)

\begin{tabular}{|c|c|c|c|c|c|}
\hline Autor & Nośniki & $\begin{array}{c}\text { Płatny } \\
\text { charakter }\end{array}$ & $\begin{array}{l}\text { Klasyfi- } \\
\text { kacja }\end{array}$ & $\begin{array}{l}\text { Określenie } \\
\text { celu }\end{array}$ & Rodzaj ekspozycji \\
\hline $\operatorname{Karrh}^{e}$ & $\begin{array}{l}\text { Programy } \\
\text { mediów maso- } \\
\text { wych }\end{array}$ & Płatne & - & - & $\begin{array}{l}\text { Włączanie produk- } \\
\text { tów markowych } \\
\text { lub identyfikato- } \\
\text { rów marek przy } \\
\text { użyciu środków } \\
\text { audio i/lub wizu- } \\
\text { alnych }\end{array}$ \\
\hline Szuman ${ }^{f}$ & Film & - & - & - & $\begin{array}{l}\text { Wykorzystanie } \\
\text { w filmie - speł- } \\
\text { niających funkcję } \\
\text { realnych rekwizy- } \\
\text { tów - markowych } \\
\text { produktów, tak aby } \\
\text { były one rozpozna- } \\
\text { walne }\end{array}$ \\
\hline 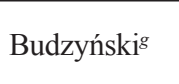 & Film fabularny & - & $\begin{array}{l}\text { Forma } \\
\text { reklamy }\end{array}$ & - & - \\
\hline Bulak $^{h}$ & $\begin{array}{l}\text { Film fabular- } \\
\text { ny bądź inny } \\
\text { utwór o podob- } \\
\text { nym zasięgu } \\
\text { oddziaływania } \\
\text { - np. telewi- } \\
\text { zja, książka, } \\
\text { fotografia, } \\
\text { klasyczna re- } \\
\text { klama, sztuka } \\
\text { teatralna itp. }\end{array}$ & - & - & - & $\begin{array}{l}\text { Umieszczenie, } \\
\text { lokowanie pro- } \\
\text { duktu danej marki } \\
\text { (firmy) }\end{array}$ \\
\hline $\begin{array}{l}\text { Czarnecki, } \\
\text { Nabakowski }^{i}\end{array}$ & $\begin{array}{l}\text { Filmy, seriale, } \\
\text { programy } \\
\text { telewizyjne, } \\
\text { teledyski }\end{array}$ & - & $\begin{array}{l}\text { Forma } \\
\text { promocji }\end{array}$ & - & $\begin{array}{l}\text { Prezentacja pro- } \\
\text { duktów lub marek }\end{array}$ \\
\hline Sobocińska ${ }^{j}$ & $\begin{array}{l}\text { Film, przedsta- } \\
\text { wienie teatral- } \\
\text { ne, książka, } \\
\text { fotografia, } \\
\text { słuchowisko } \\
\text { radiowe, gra } \\
\text { komputero- } \\
\text { wa, program } \\
\text { rozrywkowy, } \\
\text { program typu } \\
\text { reality show }\end{array}$ & - & $\begin{array}{l}\text { Instru- } \\
\text { ment ko- } \\
\text { munikacji } \\
\text { marketin- } \\
\text { gowej }\end{array}$ & $\begin{array}{l}\text { Promocja } \\
\text { marki }\end{array}$ & $\begin{array}{l}\text { Umieszczenie } \\
\text { produktu jako re- } \\
\text { kwizytu w akcji }\end{array}$ \\
\hline
\end{tabular}




\begin{tabular}{|l|l|l|l|l|l|}
\hline Nowińska ${ }^{k}$ & $\begin{array}{l}\text { Określone } \\
\text { przekazy }\end{array}$ & $\begin{array}{l}\text { Za wyna- } \\
\text { grodze- } \\
\text { niem }\end{array}$ & - & $\begin{array}{l}\text { Skutek re- } \\
\text { klamowy }\end{array}$ & $\begin{array}{l}\text { Umieszczanie } \\
\text { ściśle wybranych } \\
\text { rekwizytów }\end{array}$ \\
\hline Czarnecki ${ }^{l}$ & $\begin{array}{l}\text { Film, sztuka } \\
\text { teatralna, pro- } \\
\text { gram telewi- } \\
\text { zyjny, inne } \\
\text { nośniki audio- } \\
\text { wizualne lub } \\
\text { drukowane }\end{array}$ & $\begin{array}{l}\text { Umiesz- } \\
\text { czenie na } \\
\text { zasadach } \\
\text { komercyj- } \\
\text { nych }\end{array}$ & $\begin{array}{l}\text { Sposób } \\
\text { promocji }\end{array}$ & $\begin{array}{l}\text { Prezentacja } \\
\text { określone- } \\
\text { go wzoru } \\
\text { zachowań } \\
\text { (najczęściej } \\
\text { konsu- } \\
\text { menckich) }\end{array}$ & $\begin{array}{l}\text { Umieszczenie pro- } \\
\text { duktu lub sytuacji }\end{array}$ \\
\hline Russel, Belch ${ }^{l}$ & $\begin{array}{l}\text { Nośnik } \\
\text { rozrywkowy }\end{array}$ & $\begin{array}{l}\text { Treści roz- } \\
\text { rywkowe, } \\
\text { edukacyjne lub } \\
\text { informacyjne }\end{array}$ & & & $\begin{array}{l}\text { Celowe wkompo- } \\
\text { nowanie marki }\end{array}$ \\
\hline La Ferle, Edwards & & $\begin{array}{l}\text { Zamierzone } \\
\text { umieszczenie } \\
\text { marek za pomocą } \\
\text { środków audio } \\
\text { i/lub wideo }\end{array}$ \\
\hline Van Reijmersdal ${ }^{n}$ & $\begin{array}{l}\text { Treści redak- } \\
\text { cyjne }\end{array}$ & & & $\begin{array}{l}\text { Celowe wkompo- } \\
\text { nowanie marek }\end{array}$ \\
\hline
\end{tabular}

${ }^{a}$ S.K. Balasubramaniam, Beyond Advertising and Publicity: Hybrid Messages and Public Policy Issues, „Journal of Advertising”1994, vol. 23, issue 4

${ }^{b}$ S. Malarski, Instrumenty prawne marketingu, Wyd. Profesjonalnej Szkoły Biznesu, Kraków 1996

${ }^{c}$ P.B. Gupta, S.J. Gould, Consumers Perception of the Ethics and Acceptability of Product Placement in Movies: Product Category and Individual Differences, „Journal of Current Issues and Research in Advertising" 1997, vol. 19, issue 1

${ }^{d}$ K. Przybyłowski, S.W. Hartley, R.A. Kerin, W. Rudelius, Marketing, Dom Wydawniczy ABC, Warszawa 1998

${ }^{e}$ J.A. Karrh, Brand placement: a Review, „Journal of Current Issues and Research in Advertising" 1998, vol. 20, issue 1

${ }^{f}$ M. Szuman, Product placement, „Marketing w Praktyce” 1998, nr 2

${ }^{g}$ W. Budzyński, Reklama, Poltex, Warszawa 1999

${ }^{h}$ P. Bulak, Product placement, „Marketing iRynek” 2000, nr 4

${ }^{i}$ A. Czarnecki, T. Nabakowski, Etyczne i prawne aspekty product placement, „Marketing i Rynek" 2002, nr 4

${ }^{j}$ M. Sobocińska, Product placement - instrument budowania wizerunku marki, „Świat Marketingu" 2002, kwiecień

${ }^{k}$ E. Nowińska, Zwalczanie nieuczciwej reklamy, Kraków 2002, s. 127, za: E. Urbaniec, Product placement - medioznawstwo a marketing kreatywny, Novae Res, Gdynia 2009

${ }^{l}$ A. Czarnecki, Product placement - Niekonwencjonalny sposób promocji, PWE, Warszawa 2003

${ }^{t}$ C.A. Russell, M. Belch, A managerial investigation into the product placement industry, „Journal of Advertising Research” 2005, vol. 45, issue 1

${ }^{m}$ C. La Ferle, S.M. Edwards, Product placement: how brands appear on television, „Journal of Advertising" 2006, vol. 3, No 4

${ }^{n}$ E. Van Reijmersdal, P. Neijens, E.G. Smith, A new branch of advertising: reviewing factorsthat influence reactions to product placement, ,Journal of Advertising Research” 2009, vol. 49

Źródło: opracowanie własne. 
Aby prawidłowo zobrazować problemy definicyjne lokowania produktu, konieczne jest rozważenie dostępnych rozwiązań pod kątem występujących między nimi różnic:

- Dostępne nośniki - praktyka pokazuje, że zakres wykorzystania product placement dawno już przekroczył granice pierwotnego zastosowania - a więc jedynie w filmach i programach telewizyjnych. Marki znajdują obecnie swoje miejsce w grach komputerowych ${ }^{6}$, również społecznych ${ }^{7}$, sztukach teatralnych ${ }^{8}$, książkach $^{9}$, komiksach ${ }^{10}$, tekstach piosenek ${ }^{11}$ i teledyskach ${ }^{12}$, blogach interneto$\mathrm{wych}^{13}$, a nawet $\mathrm{w}$ atrakcjach turystycznych ${ }^{14}$. Również $\mathrm{w}$ tradycyjnych nośnikach product placement zajmuje wcześniej niespotykane nisze - np. pojawiając się w kreskówkach dla dzieci ${ }^{15}$ czy programach informacyjnych ${ }^{16}$. Nowoczesna definicja lokowania produktu powinna więc mieć charakter otwarty - akceptować szerokie spektrum możliwych nośników. Powinna być więc bliższa definicji

${ }^{6}$ M. Tokarska-Nyga, Gra w placementy, ,Magazyn Komunikacji Marketingowej Brief” 2002, nr 8; W. Wowra, Rynek reklamy w grach, „Marketing w Praktyce” 2008, nr 3; M. Belion (oprac.), Reklamy w grach - trafiona inwestycja?, „MediaRun”, 02.07.2007, http://wiadomosci.mediarun. pl/news/22013 [dostęp: 10.07.2007]; M. Belion (oprac.), Nissan: gra sposobem na promocję, „MediaRun", 13.08.2007, http://wiadomosci.mediarun.pl/news/22742 [dostęp: 20.08.2007], M. Belion (oprac.), Reklama w grach zwiększa rozpoznawalność marki, „MediaRun”, 10.08.2007, http://wiadomosci.mediarun.pl/news/22728 [dostęp: 11.08.2007].

${ }^{7} \mathrm{H}$. Chen, A. Deterding, College-aged young consumers' interpretations of product placement in social games, „Young Consumers” 2013, vol. 14, No 1.

${ }^{8}$ S. Elliott, On Broadway, ads now get to play cameo roles, „The New York Times”, 22.04.2005.

${ }^{9}$ M. Nelson, L. McLeod, Adolescent Brand Consciousness and Product Placements: Awareness, Liking and Perceived Effects on Self and Others, „International Journal of Consumer Studies” 2005, vol. 29, issue 6, s. 204.

${ }^{10}$ B. Steinberg, Look - Up In the Sky! Product Placement!, „The Wall Street Journal”, 18.04.2006.

11 S. Mohammed-Baksh, C. Callison, Hey Ya... Shake it Like a Polaroid Picture: Product Mention in Popular Music Genres, American Academy of Advertising Conference Proceedings, [b.w.m.] 2007.

12 MatD, (Subliminal) ads in video clips: Product placement in videoclips, „iMatd”, 14.07.2007, http://matdonline.free.fr/Product_placement_in_videoclips_subliminal_ads.html [dostęp: 20.07.2007]; L-vis, Product placement w Hip-Hopie, „Hip-Hop.pl”, 24.02.2003, www.hiphop.pl/teksty/projector.php?id=1046112544 [dostęp: 20.07.2007].

${ }^{13}$ Przykłady - patrz: M. Belion (oprac.), Lonelygirl15 będzie reklamować kosmetyki, „MediaRun", 25.06.2007, http://wiadomosci.mediarun.pl/news/21933 [dostęp: 25.06.2007]; M. Belion (oprac.), Kup sobie komentarz na blogu, „MediaRun”, 13.07.2007, http://wiadomosci.mediarun.pl/ news/22245 [dostęp: 13.07.2007].

${ }^{14}$ A. Weaver, Product Placement and Tourism-Oriented Environments: An Exploratory Introduction, „International Journal of Tourism Research” 2007, vol. 9, issue 4.

15 T. Grynkiewicz, V. Makarenko, Kreskówki petne reklam, „Gazeta Wyborcza”, 19.06.2005.

${ }^{16}$ L. Irwin, Product placement on CNN?, Hollywood.com 07.09.2001, http://hollywood.com/ news/Product_placement_on_CNN/1091507 [dostęp: 11.06.2007]. 
Czarneckiego czy Sobocińskiej niż spojrzenia węższego, reprezentowanego przez np. definicje Przybyłowskiego, Budzyńskiego czy Balasubramaniana ${ }^{17}$. Jednocześnie instrument ten będzie podlegać dalszemu szybkiemu rozwojowi, stąd otwarte ujęcia Karrha lub Bulaka wydają się bardziej odpowiednie. Kwestią dyskusyjną pozostaje natomiast użyte przez Karrha określenie nośników product placement jako programów mediów masowych lub zastosowane przez Bulaka otwarcie definicji na media o podobnym zasięgu oddziaływania co filmy kinowe czy programy telewizyjne - rodzą się bowiem wątpliwości, czy sztuka teatralna lub blog internetowy spełniają powyższe kryteria.

- Określenie płatnego charakteru product placement - dostępne źródła sugerują, że większość transakcji product placement to transakcje barterowe ${ }^{18}$. Część z nich nie ma jednak nawet charakteru bezpośredniej wymiany wartości, a jedynie umowy obejmującej zobowiązanie producenta markowego produktu zamieszczonego w filmie do zakupu określonej ilości reklamowego czasu antenowego $\mathrm{w}$ stacji telewizyjnej lub przeprowadzenia wiązanej ${ }^{19}$ akcji promocyjnej produktu występującego w filmie ${ }^{20}$. Powołanie się w definicji na płatny charakter transakcji zawęża pole jej zastosowania. Znacznie pojemniejsze znaczeniowo i dobrze oddające rzeczywisty stan rzeczy jest odwołanie się w definicji do komercyjnego charakteru transakcji.

- Klasyfikacja product placement jako medium promocji/komunikacji/reklamy - przyporządkowanie tego instrumentu do jednej z grup narzędzi często budzi wątpliwości i dyskusje praktyków i teoretyków marketingu. Traktowanie product placement jako jednej z odmian reklamy nie wydaje się właściwe. Zwracają uwagę różnice między tymi dwoma kategoriami, które nie pozwalają na taką klasyfikację. Przykładem mogą być przedstawione powyżej wątpliwości dotyczące płatnego charakteru lokowania produktu czy znacznie mniejsza niż w przypadku reklamy kontrola marketerów nad ostateczną formą przekazów promocyjnych. W obecnych warunkach firmy powinny patrzeć na swoją działalność promocyjną

${ }^{17}$ Zawężenie definicji powyższych autorów związane jest zresztą z czasem ich powstania większość węższych ujęć product placement powstała na przełomie XX i XXI w., kiedy skala jego zastosowania nie była jeszcze tak oczywista.

${ }^{18}$ Szacuje się, że transakcje, w których następuje bezpośrednia płatność na rynku amerykańskim stanowią mniejszość - ich udział jednak rośnie - w 1999 r. szacowano ich udział na 10\% wszystkich wymian, w badaniach z 2005 r. wskaźnik ten wyniósł 46\%, więcej patrz: L.A. Wenner, On the Ethics of Product Placement in Media Entertainment, [w:] Handbook of Product Placement in the Mass Media: New Strategies in Marketing Theory, Practice, Trends, and Ethics, ed. M.L. Galician,The Haworth Press Inc., New York 2004, s. 103 oraz S. Kehaulani Goo, Apple gets a big slice of product-placement pie, „Washington Post”, 15.04.2006.

19 Zwykle wykorzystującej motywy związane z samym filmem.

${ }^{20}$ Por. L.A. Wenner, op. cit., s. 110. 
w szerszym kontekście, klasyfikując product placement jako część zintegrowanej komunikacji marketingowej.

- Określenie celu product placement - ze względu na fakt, iż lokowanie produktu może realizować szerokie spektrum zadań, szczegółowe ich określenie nie powinno znajdować miejsca w definicji lub powinno mieć charakter ogólny. Powołanie się na miejsce product placement $\mathrm{w}$ zintegrowanej komunikacji marketingowej wystarczająco akcentuje ogólny cel zastosowania tego narzędzia.

- Rodzaj ekspozycji - traktowanie product placement jedynie jako obecności produktu w charakterze rekwizytu w scenie wydaje nam się zawężonym ujęciem. Product placement może obejmować również ekspozycję samego logo marki, odwołanie do niej w dialogu lub głębszą integrację z akcją utworu - produkt zatem nie zawsze występuje jedynie jako rekwizyt. Znacznie bliższe rzeczywistości jest więc przedstawienie product placement w szerszym ujęciu - uwzględniającym również m.in. przedstawione wyżej przykładowe sytuacje.

Do zamknięcia dyskusji definicyjnej dotyczącej lokowania produktu niezbędne jest jeszcze odwołanie do jednej definicji, nie przywołanej wcześniej - prawnej.

W Polsce do roku 2011 pojęcie lokowanie produktu (product placement) nie było uregulowane na gruncie prawa. Jedyną kategorią prawną, która regulowała podobne działania była zbliżona, ale nie tożsama z product placement ,kryptoreklama" - i to też jedynie na gruncie rynku telewizyjnego. Dopiero nowelizacja ustawy o radiofonii i telewizji (DzU, 2011, nr 85, poz. 459) wprowadza pojęcie lokowanie produktu. Uzupełnienie tych regulacji jest podyktowane harmonizacją prawa polskiego i unijnego - zgodnie z dyrektywą Unii Europejskiej 2010/13/UE „Telewizja bez granic”.

Zgodnie z bieżącymi regulacjami, lokowanie produktu to „przekaz handlowy polegający na przedstawieniu lub nawiązywaniu do towaru, usługi lub ich znaku towarowego w taki sposób, że stanowią one element samej audycji w zamian za opłatę lub podobne wynagrodzenie, a także w postaci nieodpłatnego udostępnienia towaru lub usługi"21.

Definicja ta wyraźnie wskazuje na płatny charakter ekspozycji, dodając jednak do listy możliwości transakcyjnych barter - bardzo często wykorzystywaną w telewizji formę rozliczenia. Nie klasyfikuje działań z obszaru lokowania produktu do żadnej grupy instrumentów komunikacji marketingowej i nie określa jej celu - poza ogólnym określeniem natury lokowania jako „przekaz handlowy”. Jest przykładem definicji otwarcie traktującej rodzaj ekspozycji. Z punktu widzenia praktyki branży bardzo istotne jest również to, że odnosi się jedynie do

${ }^{21}$ „Dziennik Ustaw” z 2011 r., nr 85, poz. 459. 
produkcji radiowych i telewizyjnych; rynek filmów kinowych i innych nośników nadal pozostaje nieuregulowany.

Podsumowując, product placement wymaga zastosowania możliwie szerokiej definicji. Powinna ona odzwierciedlać różne sposoby aplikacji tego instrumentu w realnych sytuacjach i być na tyle otwarta, by odpowiadała prawdopodobnym przyszłym zastosowaniom. Bliskie tym kryteriom może być więc następujące brzmienie definicji product placement:

Product placement to instrument zintegrowanej komunikacji marketingowej, polegający na eksponowaniu produktów markowych lub identyfikatorów marek przy użyciu środków audio i/lub wizualnych na zasadach komercyjnych w treści utworów rozrywkowych, artystycznych, edukacyjnych bądź informacyjnych, prezentowanych w ogólnie dostępnych mediach.

Problemy definicyjne lokowania produktu pogłębiają się w związku ze wzrostem popularności w ostatnich latach innych form integracji treści komercyjnych z natywnymi, które wykorzystują podobną zasadę ekspozycji marek.

\section{Product placement a branded entertainment}

W ostatnich latach można zauważyć rosnące zainteresowanie marketerów coraz silniejszą integracją swoich produktów i marek z akcją filmów, seriali telewizyjnych i innych nośników product placement. Takie dążenia reklamodawców nie są zaskakujące i wraz z coraz większą otwartością producentów filmowych i telewizyjnych owocują częstym wykorzystaniem wyższych poziomów integracji.

Jednocześnie niektórzy właściciele marek zaczynają traktować product placement niemal na równi z innymi instrumentami promocji, co znajduje odzwierciedlenie również $\mathrm{w}$ terminologii związanej z tym instrumentem komunikacji. Dla podkreślenia różnicy między zwykłym, standardowym product placement a strategiczną integracją marek z produktami rozrywkowymi używa się terminu branded entertainment. Branded entertainment, który do tej pory nie został udanie przetłumaczony na język polski ${ }^{22}$, jest definiowany jako „integracja komunikatów reklamowych w produkcji rozrywkowej, poprzez wkomponowywanie marek w akcję filmu, programu telewizyjnego czy innego medium rozrywkowego; taka integracja wiąże się ze wspólnym tworzeniem treści i głęboką współpracą

${ }^{22}$ Czasem używa się określenia 'markowana rozrywka', nie znalazło ono jednak szerszej akceptacji ekspertów. 
między przemysłem rozrywkowym, mediami i właścicielami marek"23. Przytoczona definicja wyraźnie akcentuje bliską współpracę między trzema stronami działań tego typu, rozumianą nie tylko jako współpracę biznesową, lecz przede wszystkim jako współpracę na poziomie kreacji produktu rozrywkowego. Podkreśla tym samym aktywną rolę właścicieli marki, np. w generowaniu pomysłów na produkty rozrywkowe.

Doświadczenia ostatnich lat pokazują, że coraz częściej występuje na rynku odwrócenie trendu, o którym pisaliśmy przy okazji historii nośników product placement - powoli wracamy do punktu wyjścia, w którym twórcą programu staje się właściciel marki wraz ze swoją agencją reklamową. W ostatnich latach nasila się współprodukowanie filmów lub programów telewizyjnych przez właścicieli marek. Szczególnym przypadkiem jest tu firma Hallmark, która od ponad 50 lat produkuje własne filmy familijne w serii „Hallmark Hall of Fame”. Inni producenci również korzystają z tej ścieżki dotarcia do klientów - np. jeden z pionierów wykorzystania produkcji telewizyjnych do celów promocji marki - Procter \& Gamble (m.in. od produkcji tej firmy ukuto w latach pięćdziesiątych XX wieku termin „opery mydlane”), również i dzisiaj prowadzi tego typu działalność. Po nawiązaniu partnerstwa z wytwórnią Paramount Pictures, Procter \& Gamble produkuje m.in. serial Dawson Creek czy Star Trek: Deep Space Nine ${ }^{24}$.

Warte odnotowania w tym miejscu jest powstanie form integracji, które do tej pory wymykały się standardowym klasyfikacjom. Jak bowiem można nazwać produkowanie w $2001 \mathrm{r}$. na zlecenie firmy BMW i dystrybuowanie w Internecie serii filmów krótkometrażowych pod nazwą The Hire? Produkcje te, tworzone przy współudziale prawdziwych gwiazd świata filmu ${ }^{25}$, zyskały znaczne zainteresowanie internautów wyrażone oszałamiającą liczbą 75 milionów pobrań filmów ze strony producenta ${ }^{26}$ (zwiększone później dystrybucją filmów w telewizjach kablowych i dzięki wydaniom DVD) i szybko znalazły naśladowców - takich jak Mazda $^{27}$, Jaguar ${ }^{28}$ czy Pirelli29. Po zakończeniu projektu BMW rozszerzył swoją

${ }^{23}$ S. Hudson, D. Hudson, Branded entertainment: a new advertising technique or product placement in disguise?, „Journal of Marketing Management” 2006, vol. 22, issue 5/6.

24 J. Neff, Sponsors behind camera, „Advertising Age” 2001, vol. 72, issue 4.

${ }^{25}$ Główna rola odtwarzana była przez Cliva Owena, w epizodach wystąpili m.in. Mickey Rourke, Madonna, Clive Owen, Forest Whitaker, Stellan Skarsgård, Gary Oldman czy James Brown, reżyserii epizodów podjęli się m.in. John Frankenheimer, Ang Lee, Guy Ritchie, John Woo i Tony Scott.

${ }^{26}$ L.Guyer, Comics help BMW get more mileage from Internet films, „Automotive News Europe" 2005, vol. 10, issue 11.

27 J. Halliday, Mazda goes viral to tout new models, ,Advertising Age” 2003, vol. 74, issue 45.

28 J. Meiners, M-B, Jaguar join web-movie marketing trend, „Automotive News Europe” 2004, vol. 9, issue 21.

${ }^{29}$ L. Wentz, Pirelli launches mini-film online, „Advertising Age” 2006, vol. 77, issue 6. 
koncepcję tworzenia własnych dzieł rozrywkowych na komiksy ${ }^{30}$ i książki czytane przez lektorów ${ }^{31}$. Trudno te działania uznać za standardowe product placement czy nawet brandintegration - przecież marka BMW nie umieszcza swoich produktów w dziełach innych autorów, tylko sama (poprzez swoją agencję reklamową) jest autorem tych dzieł. Trudno też taką formę uznać za standardową reklamę $e^{32}$. Na potrzeby opisu sukcesu filmów BMW ukuto termin advertainment - jako połączenie dwóch angielskich słów, advertising (reklama) i entertainment (rozrywka), który dobrze oddaje charakter tego typu dzieł ${ }^{33}$.

Za pewną formę advertainment należy też uznać wszelkiego rodzaju gry komputerowe budowane wokół marki - przyjmujące formę albo prostych, darmowych gier dostępnych na stronach marki, które są w stanie zaangażować swoich odbiorców na 10-15 minut, albo rozbudowanych produkcji dostępnych w standardowej dystrybucji - np. Lego Star Wars.

Termin branded entertainment obejmuje więc szeroki zestaw działań, które zakładają łączenie reklamy z dowolnymi formami rozrywki. Rdzeniem działań firm w tym zakresie jest mocno zintegrowany z akcją produktów rozrywkowych product placement, rośnie jednak rola dedykowanych produktów rozrywkowych wspierających markę - takich jak przedstawione wyżej advertainment czy advergames. Skala tych działań na rynku amerykańskim powoduje, że są one coraz poważniej traktowane przez marketerów, specjaliści sugerują wręcz konieczność traktowania branded entertainment jako rdzennego elementu strategii działań marketingowych firmy - na równi z pozostałymi instrumentami marketing-mix $x^{34}$.

W Polsce przykłady tego typu działań pojawiają się na razie w śladowych ilościach, mamy jednak i na tym polu pierwsze ambitne projekty. Dużym sukcesem okazał się emitowany w TVN program „Pascal - po prostu gotuj”, w którym kucharz Pascal Brodnicki uczy przygotowywania potraw, korzystając przy tej

${ }^{30}$ L. Guyer, op. cit.

31 K. Jackson, BMW Benefits from Internet Audio Books, „Automotive News” 2006, vol. 81, issue 6225 .

32 Choćby ze względu na strukturę kosztów - w standardowej reklamie niemal cały budżet reklamowy jest wydawany na zakup czasu i powierzchni reklamowej, udział w wydatkach na kampanię kosztów produkcji materiału reklamowego jest stosunkowo niewielki. W przypadku filmów BMW te proporcje ulegają całkowitej zmianie - koszt pięciu filmów wyprodukowanych w pierwszej z dwóch serii szacuje się na około 15 milionów dolarów, w zasadzie bez dodatkowych kosztów zakupu mediów (aczkolwiek projekt wymagał poniesienia kosztów infrastruktury informatycznej potrzebnej do zapewnienia dostępności filmów dla internautów, jednak stanowi on ułamek kosztów produkcji samych filmów). Więcej patrz: A. Vagnoni, J. Halliday, C. Taylor, Behind the wheel, ,Advertising Age" 2001, vol. 72, issue 30.

33 M. Nguen, Nothing new, but that's advertainment, „B \& T Weekly” 2007, vol. 57, issue 2639.

34 R. Parek, The matter men on what matters in branded content, „Advertising Age” 2007, vol. 78 , issue 43 . 
okazji z produktów marki Knorr. Z pozoru - klasyczny product placement - jednak historia powstania programu sugeruje, że bliżej mu do modelu advertainment. Idea całego programu powstała w firmie Unilever - właścicielu marki Knorr i właśnie ta firma jest motorem całego przedsięwzięcia i dysponuje prawami do wykorzystania wizerunku Pascala Brodnickiego ${ }^{35}$.

\section{Lokowanie produktów a reklama natywna}

$\mathrm{W}$ ostatnich latach, wraz z rozwojem nowoczesnych metod promocji firm w świecie Internetu, marketerzy zostali postawieni wobec podobnych problemów, jak w przypadku tradycyjnej reklamy. Przesyt odbiorców komercyjnymi komunikatami spowodował nie tylko rosnącą irytację reklamami typu display czy z zakresu marketingowego wykorzystania poczty elektronicznej, ale również instalowanie przez odbiorców specjalnego oprogramowania, którego celem jest ukrycie przed użytkownikiem większości komunikatów reklamowych ${ }^{36}$.

Odpowiedzią na to zagrożenie jest tzw. reklama natywna ${ }^{37}$. To nowe podejście zakłada płatne kreowanie treści promocyjnych ściśle dopasowane do formatu treści obowiązującego $\mathrm{w}$ danym serwisie lub usłudze internetowej. Zgodnie z tą filozofią, w systemie Twitter reklama natywna przyjmuje formy sponsorowanych kont i publikowanych wiadomości, w systemie Facebook - sponsorowanych wpisów, a na stronach mediów - np. na blogach czy na stronach periodyków - formę tekstowych, graficznych lub filmowych wpisów, które wiernie symulują treści redakcyjne ${ }^{38}$.

Należy jednak zaznaczyć, że podobnie jak w przypadku lokowania produktu, definicja reklamy natywnej nie jest łatwa do ustalenia. Część autorów uważa reklamę natywną za zaadaptowany do świata Internetu format artykułu sponsorowanego ${ }^{39}$.

Dodatkowym problemem definicyjnym jest określenie zakresu stosowania reklamy natywnej. Większość autorów traktuje tę reklamę jako instrument promo-

${ }^{35}$ P. Stasiak, Gwiazdy od kuchni, „Polityka” 2006, nr 15..

${ }^{36} \mathrm{~Np}$. wtyczki do przeglądarek internetowych AdBlock

${ }^{37}$ Oprócz podstawowej formy - native advertising, w języku angielskim spotyka się również określenia: customcontent, sponsoredcontent, brandedcontent, content marketing lub collaborativecontent. Por. J. Rey, Native advertising: media savior or just the new custom campaign?, „Advertising Age" 2012, issue 83, No 39.

38 Ibidem.

39 Por. D. Lovell, Native content growth means brands have big opportunities, „Marketing Week" (online edition), 20.03.2013; Interactions, Raport: Reklama natywna w Polsce, 7/2013, s. 3, http://www.interactions-europe.com/\#!mediahotspot/cfvg [dostęp: 15.10.2013]. 
cji stosowany jedynie w Internecie. Pojawiają się jednak i głosy, które rozszerzają zakres stosowania tego pojęcia również na inne pola, w szczególności tradycyjnym mediów. Gdy rozszerzymy zakres eksploatacji terminu, można nawet uznać, że lokowanie produktu jest jednym z instrumentów reklamy natywnej - wykorzystuje bowiem dokładnie tę samą metodę działania ${ }^{40}$. Jeśli przyjrzeć się bliżej przytoczonym fragmentom nowoczesnych definicji lokowania produktu Russela i Belcha, La Ferle'go, Edwardsa czy Van Reijmersdala, można również obronić tezę odwrotną - w której to reklama natywna jest jedną z odmian product placement - jest bowiem związana z integracją przekazu o charakterze komercyjnym w określonej grupie nośników.

Podobieństwo jest także zauważalne dzięki podobnym problemom związanym ze stosowaniem reklamy natywnej - szerokim echem na rynku USA odbiła się publikacja artykułu sponsorowanego na stronach „The Atlantic” wspierającego scjentologię ${ }^{41}$, w Polsce z podobną reakcją spotykają się na przykład elementy reklamy natywnej stosowane w serwisie Natemat.p1 ${ }^{42}$. Główne obszary krytyki to ukryty charakter komercyjny publikacji (zaleca się, aby sponsorowany charakter materiału był jednoznaczny) i nieumiejętna integracja treści. Krytyka jest więc podobna w naturze do prowadzonej od lat dyskusji na temat czystości komercyjnej publikowanych w prasie treści. Należy zwrócić uwagę, że tego typu dyskusje wobec tak nowego instrumentu komunikacji marketingowej (wzrost zainteresowania tym terminem można wyraźnie umiejscowić, jest to przełom 2012 i 2013 roku) w najbliższych latach prawdopodobnie mocniej przybiorą na sile - wobec pogłębiających się trendów coraz większej obecności nachalnych komercyjnych przekazów w otaczającym konsumentów świecie i pojawiających się coraz wyraźniejszych opinii krytycznych na temat komercjalizacji treści.

Podsumowując, w ostatnich latach można zauważyć rosnące zainteresowanie marketerów wszelkimi instrumentami niestandardowej komunikacji marketingowej - w tym tych, które pozwalają ominąc filtry percepcyjne klientów integrując przekaz komercyjny z rozrywkowym, informacyjnym czy edukacyjnym. W grupie pojęć wykorzystujących ten mechanizm, w ostatnich latach szczególną

${ }^{40}$ Por. V. Makarenko, Reklama natywna, czyli groźne dżinsy redaktora Machały, Wyborcza. biz, http://wyborcza.biz/biznes/1,101562,14569580,Reklama_natywna_czyli_grozne_dzinsy_redaktora_Machaly.html [dostęp: 15.10.2013] lub J. Kotarbiński, Wańka Wstańka, Subiektywny blog o sztuce marketingu, http://kotarbinski.wordpress.com/tag/reklama-natywna/ [dostęp: 14.10.2013].

${ }^{41}$ D.L. Vorkin, Inside Forbes: Before It Was Called Native Advertising, a Team in a 'Box' Had an Idea', Forbes.Com, s. 24, Business Source Complete, EBSCOhost, viewed 21 October 2013.

${ }^{42}$ V. Makarenko, Co zrobit Tomasz Lis z powerade'em. To nie byta reklama?, Wyborcza.biz, http://wyborcza.biz/biznes/1,100896,14819657,Co_zrobil_Tomasz_Lis_z_powerade_em_To_ nie_byla_reklama_.html [dostęp: 22.10.2013]; V. Makarenko, Reklama natywna... 
popularność osiągnęły trzy, najczęściej spotykane, pojęcia - lokowanie produktu, branded entertainment i reklama natywna. Tabela 2 zawiera podsumowanie różnic i podobieńst między nimi.

Tabela 2. Porównanie lokowania produktu, brandedentertainment i reklamy natywnej

\begin{tabular}{|c|c|c|c|c|c|}
\hline \multirow{2}{*}{$\begin{array}{l}\text { Pola porów- } \\
\text { nań }\end{array}$} & \multicolumn{2}{|c|}{ Lokowanie produktu } & \multirow{2}{*}{$\begin{array}{c}\text { Brandedenter- } \\
\text { tainment }\end{array}$} & \multicolumn{2}{|c|}{ Reklama natywna } \\
\hline & TV & Inne media & & $\begin{array}{l}\text { Wąskie ujęcie } \\
\text { (Internet) }\end{array}$ & $\begin{array}{l}\text { Szerokie } \\
\text { ujęcie }\end{array}$ \\
\hline Media & TV & $\begin{array}{l}\text { Film, gry } \\
\text { komputerowe, } \\
\text { literatura itp., } \\
\text { sztuki } \\
\text { teatralne, inne }\end{array}$ & Wszystkie & $\begin{array}{l}\text { Sieci społecz- } \\
\text { nościowe, } \\
\text { blogi, strony } \\
\text { newsowe }\end{array}$ & $\begin{array}{l}\text { Wszystkie } \\
\text { nośniki }\end{array}$ \\
\hline $\begin{array}{l}\text { Charakter } \\
\text { przekazu }\end{array}$ & \multicolumn{2}{|c|}{$\begin{array}{c}\text { Integracja w treść nośnika (np. } \\
\text { filmu, serialu) }\end{array}$} & \multicolumn{3}{|c|}{$\begin{array}{l}\text { Nośnik może być stworzony na potrzeby } \\
\text { ekspozycji }\end{array}$} \\
\hline $\begin{array}{l}\text { Regulacje } \\
\text { prawne }\end{array}$ & Tak & $\begin{array}{l}\text { Częściowo, } \\
\text { w zależności } \\
\text { od mediów - } \\
\text { np. prasa }\end{array}$ & Nie (poza TV) & Nie & $\begin{array}{l}\text { Częściowo, } \\
\text { w zależności } \\
\text { od mediów - } \\
\text { np. TV, prawo } \\
\text { prasowe }\end{array}$ \\
\hline $\begin{array}{l}\text { Wskazanie } \\
\text { komercyjnego } \\
\text { charakteru } \\
\text { przekazu }\end{array}$ & Obowiązkowe & Niekonieczne & Niekonieczne & Zalecane & Niekonieczne \\
\hline
\end{tabular}

Źródło: opracowanie własne.

Niezależnie jednak od różnic definicyjnych między ekspertami, należy zgodzić się, że nowoczesne formy komunikacji marketingowej - w tym te bazujące na integracji treści komercyjnych i natywnych - na stałe zagościły w środowisku biznesu. Trzeba też spodziewać się w najbliższych latach pogłębionej dyskusji na temat relacji między treściami komercyjnymi i natywnymi.

\section{Bibliografia}

Balasubramaniam S.K., Beyond Advertising and Publicity: Hybrid Messages and Public Policy Issues, „Journal of Advertising” 1994, vol. 23, issue 4

Belion M. (oprac.), Kup sobie komentarz na blogu, „MediaRun”, 13.07.2007, http://wiadomosci.mediarun.pl/news/22245 
Belion M. (oprac.), Lonelygirl15 będzie reklamować kosmetyki, „MediaRun”, 25.06.2007, http://wiadomosci.mediarun.pl/news/21933

Belion M. (oprac.), Nissan: gra sposobem na promocje, „MediaRun”, 13.08.2007, http://wiadomosci.mediarun.pl/news/22742

Belion M. (oprac.), Reklama w grach zwiększa rozpoznawalność marki, „MediaRun", 10.08.2007, http://wiadomosci.mediarun.pl/news/22728

Belion M. (oprac.), Reklamy w grach - trafiona inwestycja?, „MediaRun”, 02.07.2007, http://wiadomosci.mediarun.pl/news/22013

Budzyński W., Reklama, Poltex, Warszawa 1999

Bulak P., Product placement, „Marketing iRynek” 2000, nr 4

Chen H., Deterding A., College-aged young consumers' interpretations of product placement in social games, „Young Consumers” 2013, vol. 14, No 1

Czarnecki A., Product placement - Niekonwencjonalny sposób promocji, PWE, Warszawa 2003

Czarnecki A., Nabakowski T., Etyczne i prawne aspekty product placement, „Marketing i Rynek" 2002, nr 4

„Dziennik Ustaw” z 2011 r., nr 85, poz. 459

Elliott S., On Broadway, ads now get to play cameo roles, „The New York Times”, 22.04.2005

Grynkiewicz T., Makarenko V., Kreskówki petne reklam, „Gazeta Wyborcza”, 19.06.2005

Gupta P.B., Gould S.J., Consumers Perception of the Ethics and Acceptability of Product Placement in Movies: Product Category and Individual Differences, „Journal of Current Issues and Research in Advertising” 1997, vol. 19, issue 1

Guyer L., Comics help BMW get more mileage from Internet films, „Automotive News Europe" 2005, vol. 10, issue 11

Halliday J., Mazda goes viral to tout new models, „Advertising Age” 2003, vol. 74 , issue 45

Hudson S., Hudson D., Branded entertainment: a new advertising technique or product placement in disguise?, ,Journal of Marketing Management” 2006, vol. 22 , issue $5 / 6$

Interactions, Raport: Reklama natywna w Polsce, http://www.interactions-europe. com/\#!mediahotspot/cfvg

Irwin L., Product placement on CNN?, Hollywood.com 07.09.2001, http://hollywood.com/news/Product_placement_on_CNN/1091507

Jackson K., BMW Benefits from Internet Audio Books, „Automotive News” 2006, vol. 81 , issue 6225

Karrh J.A., Brand placement: a Review, „Journal of Current Issues and Research in Advertising" 1998, vol. 20, issue 1 
Kehaulani Goo S., Apple gets a big slice of product-placement pie, „Washington Post", 15.04.2006

Kotarbiński J., Wańka Wstańka, Subiektywny blog o sztuce marketingu, http://kotarbinski.wordpress.com/tag/reklama-natywna/

La Ferle C., Edwards S.M., Product placement: how brands appear on television, „Journal of Advertising” 2006, vol. 35, No 4

Lovell D., Native content growth means brands have big opportunities, „Marketing Week" (online edition), 20.03.2013

L-vis, Product placement w Hip-Hopie, „Hip-Hop.pl”, 24.02.2003, www.hip-hop. $\mathrm{pl} /$ teksty/projector.php?id=1046112544

Makarenko V., Co zrobit Tomasz Lis z powerade'em. To nie byta reklama?, Wyborcza.biz, http://wyborcza.biz/biznes/1,100896,14819657,Co_zrobil_Tomasz_Lis_z_powerade_em_To_nie_byla_reklama_html

Makarenko V., Reklama natywna, czyli groźne dżinsy redaktora Machaty, Wyborcza.biz, http://wyborcza.biz/biznes/1,101562,14569580,Reklama_natywna_czyli_grozne_dzinsy_redaktora_Machaly.html

Malarski S., Instrumenty prawne marketingu, Wyd. Profesjonalnej Szkoły Biznesu, Kraków 1996

MatD, (Subliminal) ads in video clips: Product placement in videoclips, ,iMatd”, 14.07.2007, http://matdonline.free.fr/Product_placement_in_videoclips_subliminal_ads.html

Meiners J., M-B, Jaguar join web-movie marketing trend, „Automotive News Europe" 2004, vol. 9, issue 21

Mohammed-Baksh S., Callison C., "Hey Ya... Shake It Like A Polaroid Picture": Product Mention in Popular Music Genres, American Academy of Advertising Conference Proceedings, 2007

Neff J., Sponsors behind camera, „Adverising Age” 2001, vol. 72, issue 4

Nelson M., McLeod L., Adolescent Brand Consciousness and Product Placements: Awareness, Liking and Perceived Effects on Self and Others, „International Journal of Consumer Studies" 2005, vol. 29, issue 6

Nguen M., Nothing new, but that's advertainment, „B \& T Weekly” 2007, vol. 57 issue 2639

Nowińska E., Zwalczanie nieuczciwej reklamy, Kraków 2002, s. 127, za: E. Urbaniec, Product placement - medioznawstwo a marketing kreatywny, Novae Res, Gdynia 2009

OMD, Polacy mają dość reklam, http://omd.pl/wskaznik-irytacji-reklama-bardzowysoki-ale-na-stabilnym-poziomie

Parek R., The matter men on what matters in branded content, „Advertising Age” 2007 , vol. 78 , issue 43 
Pilarczyk B., Niestandardowe formy komunikacji marketingowej, „Acta Universitatis Lodziensis" 2004, Folia Oeconomica 179

Przybyłowski K., Hartley S.W., Kerin R.A., Rudelius W., Marketing, Dom Wydawniczy ABC, Warszawa 1998

Rey J., Native advertising: media savior or just the new custom campaign?, „Advertising Age" 2012, issue 83, No 39

Russell C.A., Belch M., A managerial investigation into the product placement industry, „Journal of Advertising Research” 2005, vol. 45, issue 1

Sobocińska M., Product placement - instrument budowania wizerunku marki, „Świat Marketingu” 2002, kwiecień

Starcom, Startrack - Polacy, media, reklama, raport http://www.starcom.com.pl/ publikacje.shtml/12

Stasiak P., Gwiazdy od kuchni, „Polityka” 2006, nr 15

Steinberg B., Look - Up In the Sky! Product Placement!, „The Wall Street Journal", 18.04.2006

Story L., Anywhere the Eye Can See, It's Likely to See an Ad, „New York Times", 15.01.2007, http://www.nytimes.com/2007/01/15/business/ media/15everywhere.html

Szuman M., Product placement, „Marketing w Praktyce” 1998, nr 2

Tokarska-Nyga M., Gra w placementy, „Magazyn Komunikacji Marketingowej Brief' 2002, $\mathrm{nr} 8$

Vagnoni A., Halliday J., Taylor C., Behind the wheel, „Advertising Age” 2001, vol. 72 , issue 30

Van Reijmersdal E., Neijens P., Smith E.G., A new branch of advertising: reviewing factors that influence reactions to product placement, „Journal of Advertising Research" 2009, vol. 49

Vorkin L., Inside Forbes: Before It Was Called Native Advertising, a Team in a 'Box' Had an Idea', Forbes.Com, s. 24, Business Source Complete, EBSCOhost, viewed 21 October 2013.

Weaver A., Product Placement and Tourism-Oriented Environments: An Exploratory Introduction, „International Journal of Tourism Research” 2007, vol. 9 , issue 4

Wenner L.A., On the Ethics of Product Placement in Media Entertainment, [w:] Handbook of Product Placement in the Mass Media: New Strategies in Marketing Theory, Practice, Trends, and Ethics, ed. M.L. Galician, The Haworth Press Inc., New York 2004

Wentz L., Pirelli launches mini-film online, „Advertising Age” 2006, vol. 77, issue 6

Wowra W., Rynek reklamy w grach, „Marketing w Praktyce” 2008, nr 3 